\title{
Long-term Effects of Restricted Root Volume and Regulated Deficit Irrigation on Peach: I. Growth and Mineral Nutrition
}

\author{
A.M. Boland, ${ }^{1}$ P.H. Jerie, ${ }^{1,4}$ P.D. Mitchell, ${ }^{2}$ and I. Goodwin ${ }^{1}$ \\ Stone and Pome Fruit Section, Institute of Sustainable Irrigated Agriculture, Tatura Centre, Department \\ of Natural Resources and Environment, Private Bag, Tatura 3616, Australia
}

D.J. Connor ${ }^{3}$

Department of Crop Production, University of Melbourne, Parkville 3052, Victoria, Australia

AdDitional IndeX words. Prunus persica, root confinement, stone fruit

\begin{abstract}
Individual and interactive effects of restricted root volume (RRV) and regulated deficit irrigation (RDI) on vegetative growth and mineral nutrition of peach trees [Prunus persica (L.) Batsch (Peach Group) 'Golden Queen'] were studied over 3 years (1992-95). Trees were grown in lysimeters of five different volumes $(0.025,0.06,0.15,0.4$, and 1.0 $\mathbf{m}^{3}$ ) with either full or deficit (RDI) irrigation. Increasing soil volume increased vegetative growth as measured by trunk cross-sectional area (TCA) (linear and quadratic, $P<0.011$ ) and tree weight (linear, $P<0.001$ ) with the final TCA ranging from 29.0 to $51.0 \mathrm{~cm}^{2}$ and tree weight ranging from 7.2 to $12.1 \mathrm{~kg}$ for the smallest to largest volumes. Root density measured at the completion of the experiment decreased with increasing soil volume (linear and quadratic, $P<0.001$ ) with root length density declining from 24.0 to $2.0 \mathrm{~cm} \cdot \mathrm{cm}^{-3}$. RDI reduced vegetative growth by up to $70 \%$ as measured by weight of summer prunings. Root restriction was effective in controlling vegetative vigor and is a viable alternative for control of vegetative growth. Mineral nutrition did not limit tree growth.
\end{abstract}

It has been demonstrated that root systems of plants control shoot growth (Rieger and Marra, 1994) and in peach [Prunus persica (Peach Group) 'Golden Queen'], vigor is related to the volume of soil readily accessible to growth of the root system (Chalmers, 1988; Cockroft and Olsson, 1972). Rooting volume can be limited by controlling the spread and penetration of irrigation water, root competition from neighboring plants or by natural and artificial barriers in the soil.

Recent studies have shown that root restriction can limit vegetative growth with no adverse effect on fruiting efficiency providing the potential to control vigorous growth while increasing productivity, particularly in high-density orchards (Erez et al., 1992; Mandre et al., 1995; Menzel et al., 1994; Myers, 1992; Rieger and Marra, 1994; Williamson and Coston, 1990). Root restriction could be a viable alternative for control of vegetative vigor in peach, particularly in areas with a deep soil and/or where climatic conditions make it difficult to apply regulated deficit irrigation (RDI).

Field studies demonstrating the effectiveness of root restriction have not identified the mechanisms involved in the response. Williamson and Coston (1990) suggested that water stress was not involved but did not exclude mineral nutrition as a critical factor. Other authors have identified limitations due to both water and mineral nutrients (Hameed et al., 1987; Tschaplinski and Blake, 1985).

Rieger and Marra (1994) conducted an experiment with peach

Received for publication 27 July 1998. Accepted for publication 29 Sept. 1999. This research was supported by the Australian Centre for International Agricultural Research (ACIAR). We thank A.P.L. Callinan, Biometrics Services, Department of Natural Resources and Environment, for assistance with statistical analysis. The cost of publishing this paper was defrayed in part by the payment of page charges. Under postal regulations, this paper therefore must be hereby marked advertisement solely to indicate this fact.

${ }^{1}$ Horticulture irrigation scientist.

${ }^{2}$ Deceased.

${ }^{3}$ Professor.

${ }^{4}$ Stone and pome fruit section leader. seedlings and concluded that the onset of growth reduction under root confinement was not caused by a limitation of photosynthesis or water deficit, although mineral nutrient deficiency could not be ruled out for severely restricted trees. In a subsequent study, carbon resources did not influence growth and it was hypothesized that a root-derived signal was involved in the response (Mandre et al., 1995).

The long-term effects of restricted root volume (RRV) on vegetative growth, productivity, mineral nutrient status, water use, and water relations of an orchard must be established for its application in the field. Research is required to quantify the optimum root volume to achieve the appropriate suppression of vigor to optimize long-term productivity for a particular species.

In addition to the above effects, RRV is expected to play an important role in the RDI response. The successful application of RDI in the Goulburn Valley, Australia may in fact be related to the relatively shallow soils in the region which both naturally restrict root volume (Richards and Rowe, 1977a, 1977b) and allow moderate water stress to develop rapidly in a relatively small soil volume (Jerie et al., 1989).

The following research was designed to determine the separate effects of RRV and water stress on long-term growth, productivity, and water-use efficiency in peach. In addition, the interaction between the physical response to RRV and water stress associated with RDI management was studied. This first paper (I) addresses the effect on growth and mineral nutrition and a second paper (II) assesses the impact on productivity and wateruse efficiency. The effect of RRV on growth and water use of 1year-old peach trees was reported in a previous paper (Boland et al., 1994).

\section{Materials and Methods}

EXPERIMENTAL DESIGN AND CONSTRUCTION. An experiment designed to isolate the effects of RRV and RDI of 'Golden Queen' peach was conducted at Agriculture Victoria, Tatura, Australia 
Table 1. Description of irrigation and soil volume treatments.

\begin{tabular}{|c|c|c|c|c|c|}
\hline \multirow[b]{3}{*}{ Treatment } & \multirow[b]{3}{*}{$\begin{array}{l}\text { Irrigation } \\
\text { treatment }\end{array}$} & \multicolumn{4}{|c|}{ Soil vol treatment } \\
\hline & & \multirow{2}{*}{$\begin{array}{c}\text { Total } \\
\text { soil vol } \\
\left(\mathrm{m}^{3}\right)\end{array}$} & \multicolumn{3}{|c|}{ Compartment dimensions } \\
\hline & & & $\begin{array}{c}\text { Length } \\
(\mathrm{cm})\end{array}$ & $\begin{array}{c}\text { Width } \\
(\mathrm{cm})\end{array}$ & $\begin{array}{c}\text { Depth } \\
\text { (cm) }\end{array}$ \\
\hline 1 & Full & 0.025 & 25 & 25 & 40 \\
\hline 2 & Deficit & 0.025 & 25 & 25 & 40 \\
\hline 3 & Full & 0.06 & 30 & 50 & 40 \\
\hline 4 & Deficit & 0.06 & 30 & 50 & 40 \\
\hline 5 & Full & 0.15 & 60 & 60 & 40 \\
\hline 6 & Deficit & 0.15 & 60 & 60 & 40 \\
\hline 7 & Full & 0.40 & 100 & 100 & 40 \\
\hline 8 & Deficit & 0.40 & 100 & 100 & 40 \\
\hline 9 & Full & 1.00 & 100 & 120 & 80 \\
\hline 10 & Deficit & 1.00 & 100 & 120 & 80 \\
\hline
\end{tabular}

Table 2. Crop factors for full and regulated deficit irrigation (RDI) in Years 2, 3, and 4. Crop factors for the deficit treatment during the RDI period are in bold.

\begin{tabular}{lcc}
\hline \hline & \multicolumn{2}{c}{ Crop factor } \\
\cline { 2 - 3 } Month & Full irrigation & Deficit irrigation \\
\hline October & 0.4 & 0.4 \\
November & 0.6 & $\mathbf{0 . 3}$ \\
December & 0.6 & $\mathbf{0 . 3}$ \\
Early January & 0.8 & $\mathbf{0 . 4}$ \\
Late January & 1.1 & 1.1 \\
February & 1.1 & 1.1 \\
March & 1.1 & 1.1 \\
\hline
\end{tabular}

( $36^{\circ} 26^{\prime} \mathrm{S}, 145^{\circ} 16^{\prime} \mathrm{E}$ ) from 1992 to 1995 . The experiment was a randomized complete block with 10 treatments replicated four times. The design also included nearest neighbor balance to determine trends down the site and the effect of trees on neighbors (Lill, 1989). Each row consisted of 10 completely randomized treatments comprising five soil volumes by two volumes of irrigation. Soil volumes ranged from 0.025 to $1.0 \mathrm{~m}^{3}$ and irrigation was either full irrigation or deficit irrigation applied under the RDI strategy (Table 1). Each experimental unit or plot comprised four compartments- the two middle compartments were used for measurement while the two outer compartments were guards. Individual trees were planted into each compartment, there being 40 trees in each row.

The installation of the experiment has been described previously (Boland et al., 1994). In brief, each row consisted of consecutive compartments of different volumes of soil lined with plastic. Individual compartments were essentially drainage lysimeters. Water use was measured from one of the two middle compartments per plot with the three remaining compartments draining to a common system. Four replicates were measured.

ORCHARD AND IRRIGATION MANAGEMENT. The lysimeters, were positioned to form a high-density orchard $(1 \mathrm{~m}$ in- and $4 \mathrm{~m}$ between-row spacing) with a total allotted space of $4 \mathrm{~m}^{2}$ per tree. Trees were trained to a V-shaped mini-tatura trellis (van den Ende and Chalmers, 1982; van den Ende et al., 1987). Training, shaping, and pruning to the trellis were performed in summer and winter. Trees were fertigated weekly with calcium nitrate to a total annual $\mathrm{N}$ application of $100 \mathrm{~kg} \cdot \mathrm{ha}^{-1}$. Normal orchard management practices were followed. Management of pests and diseases was concerned mainly with Oriental fruit moth (Grapholita molesta Busck), two spotted spider mite (Tetranychus urticae Koch) and brown rot fungi [Monilinia fructicola (Winter) Honey and Monilinia laxa (Aderhold Ruhland) Honey].

In Year 1, all treatments were irrigated fully (Boland et al., 1994). In Years 2, 3, and 4, full irrigation was applied to five of the 10 treatments estimated from U.S. Class A pan evaporation $\left(\mathrm{E}_{\mathrm{pan}}\right)$ and known crop factors for 'Golden Queen' peaches (Table 2) (Boland et al., 1993). Irrigation amount was adjusted for measured drainage from each treatment. Maximum irrigation interval for each volume was based on 'readily available water' (volumetric water content between $0.004 \mathrm{MPa}$ and $0.06 \mathrm{MPa}$ ) of $\approx 10 \%$. Treatments were irrigated at least daily with trees in the smallest volumes irrigated up to eight times per day during maximum demand. Crop factors presented in Table 2 assumed a canopy cover of $100 \%$. To adjust for differences in tree canopy cover in Years 2 and 3, irrigation was applied proportional to the estimated canopy cover.

Deficit irrigation was applied to five treatments using the RDI management strategy over the periods described in Table 3 (PreRDI, RDI, and Post-RDI) and these are referred to throughout the paper to indicate specific stages of tree development. During the RDI period, deficit treatments received half $(50 \%)$ the full irrigation volume (Table 2).

VEGETATIVE AND ROOT GROWTH AND NUTRIENT ANALYSIS. Vegetative growth was measured over 3 years (Years 2, 3, and 4). Trunk diameter was measured $15 \mathrm{~cm}$ above-ground and increase in trunk cross-sectional area (TCA) was calculated from the start of the season to the end of RDI (pre-RDI+RDI periods) and the end of RDI to harvest (post-RDI period). Trees were pruned in summer and winter and the prunings were weighed. At the completion of the experiment (late autumn) whole trees were cut $10 \mathrm{~cm}$ above the base of the trunk and weighed.

Canopy volume was estimated midseason (before summer pruning) in Year 2 by assuming each side of the $\mathrm{V}$-shaped Tatura trellis to be a rectangular prism. For each side, depth and width at $1.5 \mathrm{~m}$ above ground and length from the middle of the $\mathrm{V}$ to the branch top were measured and canopy volume calculated. Leaves were sampled from a cubic volume $\left(0.008 \mathrm{~m}^{3}\right)$ at six representative sites from each side of the tree. Leaves were counted and total leaf area determined with a planimeter (LI-3100, LI-COR, Lincoln, Neb.). Leaf size and area per unit of canopy were calculated. Total leaf area per tree was then estimated using the canopy volume.

In Year 2, roots were sampled midseason from a $22.4 \mathrm{~mm}$ diameter core at successive $20 \mathrm{~cm}$ depths (two samples for treatments one to eight; four samples for treatments nine and 10) taken diagonally at a point midway between the tree and lysimeter

Table 3. Critical RDI periods for the regulated deficit irrigation (RDI) treatment in Years 2, 3, and 4.

\begin{tabular}{lccr}
\hline \hline Year & pre-RDI & RDI & post-RDI (harvest) \\
\hline $2(1992-93)$ & $10.22-11.19$ & $11.20-01.20$ & $01.21-03.11(03.11-03.26)$ \\
$3(1993-94)$ & $10.19-11.22$ & $11.23-01.17$ & $01.18-03.04(03.04-03.16)$ \\
$4(1994-95)$ & $10.19-11.22$ & $11.23-01.20$ & $01.21-03.06(03.06-03.27)$ \\
\hline
\end{tabular}


corner (eight cores per treatment). Core sample distance from the tree was dependent on soil volume: $\approx 12.5,25$, and $50 \mathrm{~cm}$ for treatments 1 and 2; 3, 4, 5 and 6; and 7, 8, 9 and 10, respectively. Soil was washed from the roots. Total root length was measured on a Comair rootlength scanner [Commonwealth Aircraft Corp. Ltd., Melbourne, Australia) as described by Richards et al. (1979). Roots were then oven dried at $65^{\circ} \mathrm{C}$ for $72 \mathrm{~h}$ for dry matter determination. Mean root length per cubic centimeter of soil $\left(\mathrm{cm} \cdot \mathrm{cm}^{-3}\right)$ (root length density), mean root dry weight per cubic centimeter of soil $\left(\mathrm{mg} \cdot \mathrm{cm}^{-3}\right)$ (root weight density), total length, and total weight were calculated for each soil volume.

At the conclusion of the experiment, trees were removed from individual compartments. Roots within the plastic volume were washed and weighed. Rootweight and root weight density $\left(\mathrm{kg} \cdot \mathrm{m}^{-3}\right)$ were determined.

Fifty midlateral leaves were sampled from each tree in January (midseason) and March (postharvest) of all years. Leaves were washed, oven dried at $65^{\circ} \mathrm{C}$ for $48 \mathrm{~h}$ and analyzed for B, Ca, Fe, $\mathrm{K}, \mathrm{Mg}, \mathrm{Mn}, \mathrm{Na}, \mathrm{P}$, and $\mathrm{S}$ by inductively coupled plasma optical emission spectra (Labtam Plasma Scan, ICP, Melbourne, Austra- lia); $\mathrm{Cl}$-Buchler chloridometer based on titration with silver ions; $\mathrm{N}$-semimicro Total Kjeldahl Nitrogen (ISIA Chemistry Laboratory Methods Manual Version 1.3 June, 1998).

Soil was sampled in mid-January of Year 4, midway between the tree and corner of the lysimeter. Samples were taken at 20 and $40 \mathrm{~cm}$ depths for all treatments and at $60 \mathrm{~cm}$ for the $1.0 \mathrm{~m}^{3}$ soil volume and analyzed for electrical conductivity (EC), sodium absorption ratio (SAR), and $\mathrm{pH}$.

Statistical ANALysis. Data were subjected to analysis of variance (ANOVA) using Genstat 5 (Lawes Agricultural Trust, Rothamstead Experimental Station, 1990). Treatments were irrigation and soil volumes. Soil volumes were fitted as linear and quadratic orthogonal polynomials; goodness of fit was determined by the significance of the linear and quadratic components $(P$ values $)$. The mean value for full and deficit irrigation and their least significant difference (LSD) are presented. Nearest neighbor analyses failed to improve treatment comparisons indicating there were no site trends or autocorrelation between plots.

ROOT ESCAPES. When the compartments were excavated it was established that some roots had escaped through the plastic-

Table 4. Effect of soil volume and irrigation on trunk cross-sectional area (TCA) and TCA increase in Years 2 to 4.

\begin{tabular}{|c|c|c|c|c|c|c|c|c|c|}
\hline \multirow{3}{*}{$\begin{array}{l}\text { Soil } \\
\text { vol } \\
\left(\mathrm{m}^{3}\right)\end{array}$} & \multicolumn{9}{|c|}{ TCA $\left(\mathrm{cm}^{2}\right)$} \\
\hline & \multicolumn{3}{|c|}{ Year 2} & \multicolumn{3}{|c|}{ Year 3} & \multicolumn{3}{|c|}{ Year 4} \\
\hline & $\begin{array}{c}\text { Initial } \\
(2 / 11 / 92)\end{array}$ & $\begin{array}{l}\text { End RDI } \\
(19 / 1 / 93)\end{array}$ & $\begin{array}{c}\text { Harvest } \\
(22 / 3 / 93)\end{array}$ & $\begin{array}{c}\text { Initial } \\
(20 / 10 / 93)\end{array}$ & $\begin{array}{l}\text { End RDI } \\
(19 / 1 / 94)\end{array}$ & $\begin{array}{l}\text { Harvest } \\
(3 / 3 / 94)\end{array}$ & $\begin{array}{c}\text { Initial } \\
(3 / 10 / 94)\end{array}$ & $\begin{array}{l}\text { End RDI } \\
(19 / 1 / 95)\end{array}$ & $\begin{array}{c}\text { Harvest } \\
(17 / 3 / 95)\end{array}$ \\
\hline 0.025 & 7.6 & 11.0 & 14.7 & 16.7 & 20.8 & 22.6 & 25.3 & 28.3 & 29.0 \\
\hline 0.06 & 9.6 & 13.7 & 18.2 & 19.9 & 24.7 & 26.6 & 29.1 & 32.7 & 33.1 \\
\hline 0.15 & 13.0 & 17.4 & 21.8 & 23.8 & 28.9 & 31.2 & 32.6 & 35.4 & 36.1 \\
\hline 0.4 & 15.3 & 22.1 & 28.3 & 30.6 & 36.2 & 38.4 & 41.9 & 48.0 & 49.6 \\
\hline 1.0 & 17.4 & 24.6 & 31.5 & 34.2 & 39.5 & 42.0 & 43.9 & 50.6 & 51.2 \\
\hline \multicolumn{10}{|c|}{$\begin{array}{l}\text { Significance of } \\
\text { contrast ( } P \text { value })\end{array}$} \\
\hline Linear & $<0.001$ & $<0.001$ & $<0.001$ & $<0.001$ & $<0.001$ & $<0.001$ & $<0.001$ & $<0.001$ & $<0.001$ \\
\hline Quadratic & $c<0.001$ & $<0.001$ & $<0.001$ & $<0.001$ & 0.004 & 0.009 & 0.011 & 0.009 & 0.006 \\
\hline \multicolumn{10}{|c|}{ Volume $\times$ irrigation } \\
\hline ( $P$ value $)$ & NS & NS & NS & NS & NS & NS & NS & NS & NS \\
\hline \multicolumn{10}{|l|}{ Irrigation } \\
\hline Deficit & 12.4 & 17.2 & 22.4 & 24.5 & 29.3 & 31.5 & 34.5 & 39.2 & 40.0 \\
\hline Full & 12.7 & 18.3 & 23.4 & 25.5 & 30.8 & 32.8 & 34.6 & 38.8 & 39.6 \\
\hline \multirow[t]{4}{*}{$\mathrm{LSD}_{0.05}$} & NS & NS & NS & NS & NS & NS & NS & NS & NS \\
\hline & \multicolumn{6}{|c|}{ TCA increase $\left(\mathrm{cm}^{2}\right)$} & & & \\
\hline & \multicolumn{2}{|c|}{ Year 2} & \multicolumn{2}{|c|}{ Year 3} & \multicolumn{2}{|c|}{ Year 4} & & & \\
\hline & re-RDI+RDI & $\overline{\text { post-RDI }}$ & pre-RDI+RDI & $\overline{\text { post-RDI }}$ & pre-RDI+RDI & $\overline{\text { post-RDI }}$ & & & \\
\hline$\overline{0.025}$ & 3.42 & 3.69 & 4.15 & 1.79 & 3.00 & 0.66 & & & \\
\hline 0.06 & 4.06 & 4.54 & 4.80 & 1.91 & 3.60 & 0.44 & & & \\
\hline 0.15 & 4.37 & 4.42 & 5.10 & 2.29 & 2.84 & 0.70 & & & \\
\hline 0.4 & 6.86 & 6.15 & 5.63 & 2.26 & 6.06 & 1.59 & & & \\
\hline 1.0 & 7.26 & 6.87 & 5.39 & 2.42 & 6.67 & 0.66 & & & \\
\hline \multicolumn{10}{|c|}{$\begin{array}{l}\text { Significance of } \\
\text { contrast ( } P \text { value })\end{array}$} \\
\hline Linear & $<0.001$ & $<0.001$ & 0.354 & 0.258 & 0.003 & 0.604 & & & \\
\hline Quadratic & 0.013 & 0.138 & 0.322 & 0.542 & 0.263 & 0.009 & & & \\
\hline \multicolumn{10}{|c|}{ Volume $\times$ irrigation } \\
\hline$(P$ value $)$ & NS & NS & NS & NS & NS & NS & & & \\
\hline \multicolumn{10}{|l|}{ Irrigation } \\
\hline Deficit & 4.78 & 5.19 & 4.76 & 2.27 & 4.70 & 0.78 & & & \\
\hline Full & 5.60 & 5.07 & 5.27 & 2.00 & 4.17 & 0.84 & & & \\
\hline $\mathrm{LSD}_{0.05}$ & NS & NS & NS & NS & NS & NS & & & \\
\hline
\end{tabular}


mainly from the two smallest volumes. Roots were observed to have penetrated sidewalls with few roots through the base indicating there were no obvious weak points (e.g., corners). For each tree, the diameters of these roots were measured at the interface and root cross-sectional area (RCA) was calculated. Root crosssectional area was included as a covariate in the ANOVA but was not significant in any analyses and was consequently omitted. The possible effect of the escaped roots on the interpretation of results is addressed in the discussion.

\section{Results}

VegetATIVE GROWTH. On all measurement dates there was a linear and quadratic effect of soil volume on TCA. There was no influence of irrigation treatment on TCA (Table 4). At the start of Year 2, TCA ranged from 7.6 to $17.4 \mathrm{~cm}^{2}$ for the smallest to largest soil volume treatments. This range was 29.0 to $51.2 \mathrm{~cm}^{2}$ by completion of the experiment.

In Year 2, soil volume had a positive linear effect on TCA increase in the pre-RDI+RDI and post-RDI periods (Table 4). There was no effect of soil volume on TCA increase in Year 3 but there was a linear response to soil volume in the pre-RDI+RDI period of Year 4. There was no effect of irrigation treatment in Years 2, 3, and 4 (Table 4). TCA increase during the preRDI+RDI period was similar between years with an average increase of $4.9 \mathrm{~cm}^{2}$. However, TCA increase during the post-RDI period declined over years with the following means: Year 2$5.1 \mathrm{~cm}^{2}$, Year $3-2.1 \mathrm{~cm}^{2}$, Year $4-0.8 \mathrm{~cm}^{2}$.

In Year 2, there was a positive linear and quadratic effect of soil volume on weight of summer prunings (Table 5). Deficit irrigation reduced summer pruning weight. Response in Year 4 was similar to Year 2, with a linear and quadratic component for soil volume and a reduction under deficit irrigation. There was an interaction between irrigation treatment and soil volume in this year. There was no effect of soil volume or irrigation treatment on summer pruning weights in Year 3. The average amount of vegetative growth pruned in summer was $1.5,4.4$, and $2.6 \mathrm{~kg}$ in Years 1, 2 and 3, respectively. Soil volume had a positive linear effect on weight of winter prunings in all years (Table 5).
Irrigation treatment had no effect on weight of winter prunings.

Tree weight at completion of the experiment was influenced by soil volume with positive linear and quadratic effects (Table $5)$. There was no effect of irrigation treatment. Trees weighed from 7.2 to $12.2 \mathrm{~kg}$ for the smallest to largest soil volumes.

In Year 2, there was a positive linear effect of soil volume on leaf size (Table 6). Leaf size was reduced under deficit irrigation. Leaf area per unit of canopy volume, canopy volume, and total leaf area per tree were positively related to soil volume. Deficit irrigation reduced canopy volume. Total leaf area per tree ranged from $\approx 16$ to $60 \mathrm{~m}^{2}$ for the smallest to largest soil volumes; equivalent to a leaf area index (LAI) of 4 to 15 .

RoOT GROWTH. There was a negative linear relationship between soil volume and root length density and root weight density measured in Year 2 (Table 7). Total root length and total root weight were positively related to soil volume (Table 7). Total root length varied from 5.9 to $20.5 \mathrm{~km}$ and total root weight ranged from 0.2 to $1.3 \mathrm{~kg}$ for the 0.025 to $1.0 \mathrm{~m}^{3}$ compartments.

At the completion of the experiment, there was a small decrease in total root weight in compartments with increasing soil volume (Table 8). Calculated root density decreased with increasing soil volume. There was no influence of irrigation treatment on calculated root density.

There were generally few roots (no more than 10) penetrating the plastic and these roots ranged in cross sectional area from small $\left(<2 \mathrm{~cm}^{2}\right)$ to a few individual roots which were categorized as large $\left(>10 \mathrm{~cm}^{2}\right)$. These large roots were generally associated with trees larger than the treatment average. Total area of escapes (RCA) was significantly greater for the two smallest volumes (Table 8).

The relationship between escaped roots (RCA) and total tree weight at the completion of the experiment for the two smallest volumes $\left(0.025\right.$ and $\left.0.06 \mathrm{~m}^{3}\right)$ was assessed (Fig. 1). Tree weight and RCA were correlated with $r^{2}$ of 0.482 and 0.686 for the 0.025 and $0.06 \mathrm{~m}^{3}$ soil volumes, respectively.

LEAF MINERAL NUTRIENT AND SOIL ANALYSIS. Isolated effects were noted for the various nutrients. Consistent differences were only evident, however, for leaf $\mathrm{K}$ and Mn concentration (Table 9). There was a positive linear effect of soil volume on leaf $\mathrm{K}$ for all

Table 5. Effect of soil volume and irrigation on summer and winter pruning weights for Year 2 to 4 and weight of whole trees at the completion of the experiment (end of Year 4).

\begin{tabular}{|c|c|c|c|c|c|c|c|c|c|}
\hline \multirow{3}{*}{$\begin{array}{l}\text { Soil } \\
\text { vol } \\
\left(\mathrm{m}^{3}\right)\end{array}$} & \multicolumn{5}{|c|}{ Summer pruning (kg) } & & & & \multirow{3}{*}{$\begin{array}{c}\text { Tree wt }(\mathrm{kg}) \\
\text { (end } \\
\text { experiment) }\end{array}$} \\
\hline & \multirow[b]{2}{*}{ Year 2} & \multirow[b]{2}{*}{ Year 3} & \multicolumn{3}{|c|}{ Year 4} & \multicolumn{3}{|c|}{ Winter pruning $(\mathrm{kg})$} & \\
\hline & & & Mean & Deficit & Full & Year 2 & Year 3 & Year 4 & \\
\hline 0.025 & 0.39 & 3.28 & 1.34 & 0.91 & 1.78 & 1.64 & 1.25 & 1.18 & 7.19 \\
\hline 0.06 & 0.82 & 4.41 & 2.29 & 1.28 & 3.31 & 2.06 & 1.61 & 1.53 & 8.58 \\
\hline 0.15 & 0.83 & 4.06 & 2.49 & 2.79 & 2.20 & 2.21 & 1.53 & 1.44 & 8.69 \\
\hline 0.4 & 2.42 & 5.21 & 3.72 & 4.26 & 3.17 & 3.03 & 1.91 & 1.98 & 12.52 \\
\hline 1.0 & 2.96 & 4.77 & 2.96 & 1.81 & 4.11 & 3.44 & 2.02 & 2.03 & 12.14 \\
\hline \multicolumn{10}{|c|}{$\begin{array}{l}\text { Significance of } \\
\text { contrast ( } P \text { value })\end{array}$} \\
\hline Linear & $<0.001$ & 0.242 & 0.024 & & & $<0.001$ & 0.013 & 0.005 & $<0.001$ \\
\hline Quadratic & 0.003 & 0.214 & 0.003 & & & 0.046 & 0.230 & 0.106 & 0.015 \\
\hline \multicolumn{10}{|c|}{ Volume $\times$ irrigation } \\
\hline \multicolumn{10}{|l|}{ Irrigation } \\
\hline Deficit & 1.09 & 4.10 & 2.21 & & & 2.38 & 1.73 & 1.66 & 9.87 \\
\hline Full & 1.88 & 4.59 & 2.92 & & & 2.57 & 1.60 & 1.60 & 9.78 \\
\hline $\mathrm{LSD}_{0.05}$ & 0.694 & NS & 0.763 & & & NS & NS & NS & NS \\
\hline
\end{tabular}


Table 6. Effect of soil volume and irrigation on leaf size, leaf area per unit canopy volume, total canopy volume, and total leaf area in Year 2 (before summer pruning).

\begin{tabular}{|c|c|c|c|c|}
\hline $\begin{array}{l}\text { Soil } \\
\text { vol } \\
\left(\mathrm{m}^{3}\right)\end{array}$ & $\begin{array}{l}\text { Leaf } \\
\text { size } \\
\left(\mathrm{cm}^{2}\right)\end{array}$ & $\begin{array}{c}\text { Leaf area/ } \\
\text { canopy } \\
\left(\mathrm{m}^{2} \cdot \mathrm{m}^{-3}\right)\end{array}$ & $\begin{array}{c}\text { Canopy } \\
\text { vol } \\
\left(\mathrm{m}^{3}\right)\end{array}$ & $\begin{array}{c}\text { Total leaf } \\
\text { area } \\
\left(\mathrm{m}^{2}\right)\end{array}$ \\
\hline 0.025 & 26.8 & 8.62 & 1.95 & 16.88 \\
\hline 0.06 & 29.2 & 8.73 & 2.79 & 23.64 \\
\hline 0.15 & 30.9 & 9.11 & 3.42 & 30.56 \\
\hline 0.4 & 34.1 & 10.79 & 4.40 & 47.84 \\
\hline 1.0 & 34.0 & 12.27 & 4.94 & 60.16 \\
\hline \multicolumn{5}{|l|}{ Significance of contrast ( $P$ value $)$} \\
\hline Linear & $<0.001$ & $<0.001$ & $<0.001$ & $<0.001$ \\
\hline Quadratic & 0.005 & 0.386 & $<0.001$ & 0.005 \\
\hline Volume $\times$ irrigation ( $P$ value $)$ & NS & NS & NS & NS \\
\hline \multicolumn{5}{|l|}{ Irrigation } \\
\hline Deficit & 29.65 & 9.98 & 3.25 & 38.20 \\
\hline Full & 32.25 & 9.82 & 3.75 & 33.44 \\
\hline $\mathrm{LSD}_{0.05}$ & 2.22 & NS & 0.378 & NS \\
\hline
\end{tabular}

Table 7. Effect of soil volume and irrigation on root length and weight per unit soil volume and total root length and weight in Year 2.

\begin{tabular}{|c|c|c|c|c|}
\hline $\begin{array}{l}\text { Soil } \\
\text { vol } \\
\left(\mathrm{m}^{3}\right)\end{array}$ & $\begin{array}{c}\text { Root length } \\
\text { density } \\
\left(\mathrm{cm} \cdot \mathrm{cm}^{-3}\right)\end{array}$ & $\begin{array}{l}\text { Root wt } \\
\text { density } \\
\left(\mathrm{mg} \cdot \mathrm{cm}^{-3}\right)\end{array}$ & $\begin{array}{c}\text { Total root } \\
\text { length } \\
(\mathrm{km})\end{array}$ & $\begin{array}{c}\text { Total root } \\
\text { wt } \\
(\mathrm{kg})\end{array}$ \\
\hline 0.025 & 23.4 & 8.51 & 5.9 & 0.21 \\
\hline 0.06 & 23.9 & 10.54 & 14.3 & 0.63 \\
\hline 0.15 & 10.5 & 5.26 & 15.7 & 0.79 \\
\hline 0.4 & 4.2 & 3.28 & 16.7 & 1.31 \\
\hline 1.0 & 2.0 & 1.36 & 20.5 & 1.32 \\
\hline \multicolumn{5}{|l|}{ Significance of contrast ( $P$ value $)$} \\
\hline Linear & $<0.001$ & $<0.001$ & 0.008 & $<0.001$ \\
\hline Quadratic & 0.013 & 0.068 & 0.217 & 0.012 \\
\hline Volume $\times$ irrigation ( $P$ value $)$ & NS & NS & NS & NS \\
\hline \multicolumn{5}{|l|}{ Irrigation } \\
\hline Deficit & 12.2 & 5.10 & 12.9 & 0.71 \\
\hline Full & 13.4 & 6.49 & 16.3 & 1.01 \\
\hline $\mathrm{LSD}_{0.05}$ & NS & NS & NS & 0.347 \\
\hline
\end{tabular}

dates. Deficit irrigation reduced $\mathrm{K}$ at the end of RDI in all years. Leaf Mn was negatively related to soil volume on all dates. There was no effect of irrigation treatment on leaf Mn. Although there was an effect of soil volume on leaf $\mathrm{K}$ and $\mathrm{Mn}$, concentrations were generally within the adequate range $(\mathrm{K}-2 \%$ to $3 \%$; $\mathrm{Mn}-$ 40 to $160 \mathrm{mg} \mathrm{kg}^{-1}$ ) (Robinson et al., 1997). Importantly, soil volume and irrigation treatments did not change this categorization.

There was no effect of either soil volume or irrigation treatment on soil EC and SAR sampled during the fourth season (Table 10). Soil pH was significantly influenced by soil volume with the smallest volumes having a lower $\mathrm{pH}$. All EC, SAR, and $\mathrm{pH}$ values were considered satisfactory for stone fruit production.

\section{Discussion}

This experiment was designed to investigate the effects of soil volume and irrigation, and their interactions. In general the effects of soil volume were more pronounced than those of RDI. While these effects are discussed the potential influence of escaped roots must be considered in the assessment.

Analysis of responses relied on the assigned root volumes however, root escapes were observed at the completion of the experiment. Root escape would be dependent upon the season, with most root activity for mature trees occurring in spring and autumn (Cockcroft and Olsson, 1972; Williamson and Coston, 1989). Trees were planted in late spring and it is unlikely that there were any escapes in Years 1 and 2 as roots of the young trees filled the soil volume. It can only be assumed that root escapes increased progressively in subsequent years and in Years 3 and 4, individual trees in the two smallest volumes demonstrated increased vigor and trunk growth.

A strong relationship between TCA and total weight of trees has been shown (Chalmers and van den Ende, 1975; Westwood and Roberts, 1970) and in this experiment, TCA was strongly correlated to weight of trees in the 0.025 and $0.06 \mathrm{~m}^{3}$ soil volumes $\left(r^{2}=0.96\right.$ and 0.98 respectively). A similar relationship between RCA and total weight of roots was assumed. The inclusion of RCA as a covariate failed to improve the analysis partly because of the distribution of RCA across treatments. The discussion therefore relies on the presented ANOVA for soil volume and irrigation. In order to determine which data can be interpreted with certainty, it is necessary to evaluate the possible effects of root escape on measured parameters. 
Table 8. Effect of soil volume and irrigation on total root weight and density in the compartment, root to shoot ratio (internal total root weight to total tree weight) and the root cross-sectional area (RCA) of escaped roots at the completion of the experiment (Year 4).

\begin{tabular}{|c|c|c|c|c|}
\hline $\begin{array}{l}\text { Soil } \\
\text { vol } \\
\left(\mathrm{m}^{3}\right)\end{array}$ & $\begin{array}{c}\text { Total root } \\
\text { wt } \\
(\mathrm{kg})\end{array}$ & $\begin{array}{c}\text { Root } \\
\text { density } \\
\left(\mathrm{kg} \cdot \mathrm{m}^{-3}\right)\end{array}$ & $\begin{array}{c}\text { Root to } \\
\text { shoot } \\
\text { ratio }\end{array}$ & $\begin{array}{l}\mathrm{RCA} \\
\left(\mathrm{cm}^{2}\right)\end{array}$ \\
\hline 0.025 & 7.63 & 305.1 & 1.17 & 25.6 \\
\hline 0.06 & 10.07 & 167.9 & 1.25 & 17.7 \\
\hline 0.15 & 11.02 & 73.4 & 1.37 & 12.7 \\
\hline 0.4 & 7.84 & 19.6 & 0.64 & 3.3 \\
\hline 1.0 & 7.07 & 7.1 & 0.59 & 0.7 \\
\hline \multicolumn{5}{|l|}{ Significance of contrast ( $P$ value $)$} \\
\hline Linear & 0.035 & $<0.001$ & $<0.001$ & $<0.001$ \\
\hline Quadratic & 0.728 & $<0.001$ & 0.004 & 0.008 \\
\hline Volume $\times$ irrigation ( $P$ value $)$ & NS & NS & NS & NS \\
\hline \multicolumn{5}{|l|}{ Irrigation } \\
\hline Deficit & 8.88 & 117.2 & 1.02 & 12.2 \\
\hline Full & 8.57 & 112.1 & 0.99 & 11.8 \\
\hline $\mathrm{LSD}_{0.05}$ & NS & NS & NS & NS \\
\hline
\end{tabular}

The area of roots outside the compartment would influence top growth (Richards, 1981; Richards and Rowe, 1977a, 1977b). RCA and tree weight of the two smallest soil volumes were correlated indicating that tree weight would be $\approx 3$ and $4 \mathrm{~kg}$ for the 0.025 and $0.06 \mathrm{~m}^{3}$ soil volumes, respectively, had there been no escapes $(\mathrm{RCA}=0)($ Fig. 1). Differences for vegetative responses are therefore valid and would have been accentuated under conditions of full containment. Given the potential influences of root escapes, the effect of soil volume and irrigation on vegetative and root growth, mineral nutrient and soil analysis, and dry matter partitioning are discussed.

It has been shown previously that root restriction reduces vegetative growth of deciduous fruit trees (Mandre et al., 1995; Myers, 1992; Richards and Rowe, 1977a, 1977b; Rieger and Marra, 1994; Williamson and Coston, 1990; Williamson et al., 1992). The reduction of all growth parameters resulting from decreased soil volume was also apparent in our experiment (Tables 4, 5 and 6). This effect was clearly demonstrated in Years 2 and 4. However, in Year 3, soil volume did not influence summer pruning or TCA increase (Tables 4 and 5). The combination of wetter conditions during the RDI period in Year 3 and escaped roots in the smaller volumes may have been the cause.

RDI has been adopted extensively to control vegetative growth of deciduous trees (Boland et al., 1993; Caspari et al., 1994; Chalmers et al., 1986; Fereres and Goldhamer, 1990; Lampinen et al., 1995; Mitchell et al., 1989). In contrast to the significant effect of soil volume, RDI had minimal influence on tree growth in the current experiment (Tables 4, 5 and 6). This was partly due to the level of RDI imposed (50\% of full irrigation). This compares with a field study where RDI levels of $12.5 \%$ and $25 \%$ of the control decreased vegetative growth (summer pruning weights and TCA) by more than half (Mitchell and Chalmers, 1982). In our experiment, root escapes would also have influenced the RDI response particularly in Year 3 with heavy rain during the RDI period.

There was little effect of soil volume or RDI on leaf mineral nutrient concentrations except for Mn and K (Table 9). Overall, nutrient concentrations were within the adequate range with little difference between years. There have been varied reports of root restriction effects on mineral nutrition. Hameed et al. (1987) proposed nutrient limitations as part of the root restriction re- sponse. For peach, root restriction reduced $\mathrm{P}$ and $\mathrm{Cu}$ (Williamson and Coston, 1990) and influenced P, K, Ca, Mg, Zn, and B (Rieger and Marra, 1994). Root restriction reduced N, P, Ca, Mg, Fe, Mn, $\mathrm{Al}$, and $\mathrm{Cu}$ of spreading euonymus (Euonymus kiautschovica Loes. 'Sieboldiana') (Dubik et al., 1990), while Menzel et al. (1994) was unable to demonstrate significant change in nutrient concentration with root restriction of passionfruit (Passiflora edulis f. edulis and P. edulis f. flavicarpa). RDI was shown to increase leaf $\mathrm{N}$ and $\mathrm{Zn}$ and decrease $\mathrm{Ca}$ of peach (Williamson and Coston, 1990). It is possible that escaped roots influenced nutrient uptake, although, the inconsistent and small differences in nutrient concentrations over the 3 years suggest this was not the case.

Soil EC, SAR, and $\mathrm{pH}$ were satisfactory for the production of stone fruit (Table 10). There was no effect of soil volume or irrigation treatment on EC or SAR although decreasing soil volume caused a decline in soil $\mathrm{pH}$. Analysis of leaves and soil, indicate that mineral nutrition was not limiting.

In Year 2, root density (weight and length) decreased with increasing soil volume (Table 7). When calculated over the total volume, root length and weight increased with a 4- to 6-fold difference between the smallest and largest soil volumes. This would generally be expected given the functional equilibrium between root to shoot ratio (Richards, 1986; Richards and Rowe, 1977b; Rieger and Marra, 1994).

In contrast to the above, at the completion of the experiment,

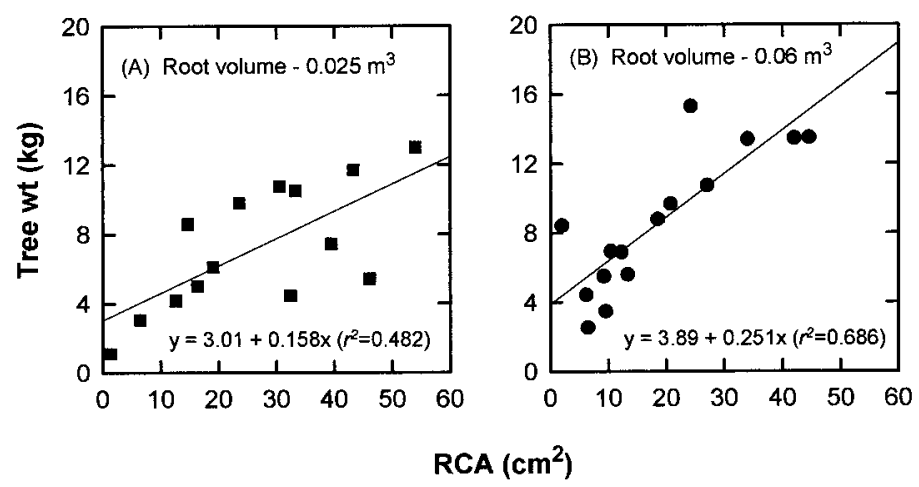

Fig. 1. Relationship of RCA (cm) of escaped roots at excavation and tree top fresh weight $(\mathrm{kg})$ in Year 4 for (A) 0.025 and (B) $0.06 \mathrm{~m}^{3}$ soil volumes. 
Table 9. Effect of soil volume and irrigation on leaf mineral nutrient concentration for $\mathrm{K}(\%)$ and $\mathrm{Mn}\left(\mathrm{mg}^{\mathrm{k}} \mathrm{kg}^{-1}\right)$ in Years 2 to 4 (end of RDI and harvest) ( $\mathrm{A}=$ adequate; $\mathrm{M}=$ marginal).

\begin{tabular}{|c|c|c|c|c|c|c|c|c|c|c|c|c|}
\hline \multirow{3}{*}{$\begin{array}{l}\text { Soil } \\
\text { vol }\end{array}$} & \multicolumn{6}{|c|}{$\mathrm{K}(\%)$} & \multicolumn{6}{|c|}{$\operatorname{Mn}\left(\mathrm{mg} \cdot \mathrm{kg}^{-1}\right)$} \\
\hline & \multicolumn{2}{|c|}{ Year 2} & \multicolumn{2}{|c|}{ Year 3} & \multicolumn{2}{|c|}{ Year 4} & \multicolumn{2}{|c|}{ Year 2} & \multicolumn{2}{|c|}{ Year 3} & \multicolumn{2}{|c|}{ Year 4} \\
\hline & RDI & Harvest & RDI & Harvest & RDI & Harvest & RDI & Harvest & RDI & Harvest & RDI & Harvest \\
\hline$\left(\mathrm{m}^{3}\right)$ & A & A & A & $\mathrm{M}-\mathrm{A}$ & A & $\mathrm{M}-\mathrm{A}$ & A & $\mathrm{A}$ & A & A & A & A \\
\hline 0.025 & 2.37 & 2.07 & 2.79 & 1.31 & 1.82 & 1.25 & 90.9 & 110.2 & 140.1 & 155.3 & 96.1 & 100.7 \\
\hline 0.06 & 2.35 & 2.05 & 2.88 & 1.39 & 2.03 & 1.52 & 80.5 & 98.0 & 117.5 & 117.4 & 88.2 & 100.5 \\
\hline 0.15 & 2.59 & 2.09 & 3.02 & 1.51 & 2.35 & 1.87 & 69.0 & 87.6 & 109.0 & 132.4 & 84.2 & 107.4 \\
\hline 0.4 & 2.66 & 2.00 & 3.22 & 1.54 & 2.41 & 2.01 & 57.1 & 64.1 & 73.4 & 88.5 & 59.6 & 74.9 \\
\hline 1.0 & 2.65 & 2.34 & 3.23 & 1.60 & 2.56 & 1.97 & 47.5 & 45.7 & 59.2 & 67.9 & 58.9 & 65.7 \\
\hline \multicolumn{13}{|c|}{$\begin{array}{l}\text { Significance of } \\
\text { contrast ( } P \text { value })\end{array}$} \\
\hline Linear & 0.001 & 0.006 & 0.003 & 0.013 & $<0.001$ & 0.002 & $<0.001$ & $<0.001$ & $<0.001$ & $<0.001$ & 0.005 & 0.006 \\
\hline Quadratic & 0.005 & 0.081 & 0.039 & 0.145 & 0.001 & 0.003 & 0.007 & 0.005 & 0.007 & 0.096 & 0.078 & 0.446 \\
\hline $\begin{array}{l}\text { Volume } \times \text { irri } \\
(P \text { value })\end{array}$ & NS & NS & NS & NS & NS & NS & NS & 0.021 & NS & NS & NS & NS \\
\hline \multicolumn{13}{|l|}{ Irrigation } \\
\hline Deficit & 2.41 & 2.05 & 2.89 & 1.43 & 2.12 & 1.65 & 66.2 & 77.9 & 93.2 & 106.7 & 72.9 & 83.9 \\
\hline Full & 2.63 & 2.16 & 3.17 & 1.51 & 2.35 & 1.80 & 71.8 & 84.3 & 106.5 & 117.8 & 81.8 & 95.8 \\
\hline $\mathrm{LSD}_{0.05}$ & 0.113 & NS & 0.187 & NS & 0.138 & NS & NS & NS & NS & NS & NS & NS \\
\hline
\end{tabular}

Table 10. Effect of soil volume and irrigation on soil $\mathrm{EC}_{(1: 5)}, \mathrm{SAR}_{(1: 5)}$, and $\mathrm{pH}_{(\mathrm{CaCl})}$ recorded at the end of RDI in Year 4 from midway between the tree and corner of the compartment.

\begin{tabular}{|c|c|c|c|c|c|c|c|c|c|c|}
\hline \multirow{3}{*}{$\begin{array}{l}\text { Soil } \\
\text { vol } \\
\left(\mathrm{m}^{3}\right)\end{array}$} & & \multicolumn{3}{|c|}{$\mathrm{EC}_{(1: 5)}$} & \multicolumn{3}{|c|}{$\operatorname{SAR}_{(1: 5)}$} & \multicolumn{3}{|c|}{$\mathrm{pH}_{(\mathrm{CaCl} 12)}$} \\
\hline & & \multirow[b]{2}{*}{$20 \mathrm{~cm}$} & \multirow[b]{2}{*}{$40 \mathrm{~cm}$} & \multirow[b]{2}{*}{$60 \mathrm{~cm}$} & \multicolumn{3}{|c|}{ Depth $(\mathrm{cm})$} & \multirow[b]{2}{*}{$20 \mathrm{~cm}$} & \multirow[b]{2}{*}{$40 \mathrm{~cm}$} & \multirow[b]{2}{*}{$60 \mathrm{~cm}$} \\
\hline & & & & & $20 \mathrm{~cm}$ & $40 \mathrm{~cm}$ & $60 \mathrm{~cm}$ & & & \\
\hline \multirow[t]{2}{*}{0.025} & Deficit & 0.22 & 0.29 & & 0.58 & 0.59 & & 5.4 & 5.3 & \\
\hline & Full & 0.49 & 0.41 & & 0.40 & 0.30 & & 5.5 & 5.3 & \\
\hline \multirow[t]{2}{*}{0.06} & Deficit & 0.47 & 0.55 & & 0.43 & 0.46 & & 5.6 & 5.3 & \\
\hline & Full & 0.11 & 0.18 & & 0.26 & 0.36 & & 5.8 & 5.5 & \\
\hline \multirow[t]{2}{*}{0.15} & Deficit & 0.30 & 0.42 & & 0.26 & 0.30 & & 5.7 & 5.4 & \\
\hline & Full & 0.38 & 0.41 & & 0.33 & 0.46 & & 5.5 & 5.4 & \\
\hline \multirow[t]{2}{*}{0.4} & Deficit & 0.36 & 0.32 & & 0.38 & 0.38 & & 6.1 & 6.2 & \\
\hline & Full & 0.39 & 0.33 & & 0.18 & 0.33 & & 5.9 & 6.2 & \\
\hline \multirow[t]{2}{*}{1.0} & Deficit & 0.36 & 0.29 & 0.77 & 0.19 & 0.15 & 0.13 & 6.1 & 5.9 & 6.1 \\
\hline & Full & 0.28 & 0.25 & 0.59 & 0.19 & 0.20 & 0.19 & 5.8 & 5.8 & 6.2 \\
\hline \multicolumn{11}{|c|}{$\begin{array}{l}\text { Significance of } \\
\text { contrast ( } P \text { value })\end{array}$} \\
\hline \multicolumn{2}{|c|}{ Linear } & 0.725 & 0.801 & & 0.066 & 0.333 & & 0.003 & $<0.001$ & \\
\hline \multicolumn{2}{|c|}{ Quadratic } & 0.887 & 0.570 & & 0.134 & 0.708 & & 0.737 & 0.191 & \\
\hline \multicolumn{2}{|c|}{ Irrigation } & 0.952 & 0.558 & & 0.070 & 0.304 & & 0.87 & 0.80 & \\
\hline
\end{tabular}

there was no effect of soil volume on the total weight of roots within compartments (Table 8). Calculated root density was 40 times greater in the smallest compared with the largest volume. Ingram et al. (1987) demonstrated minimal increases in root density under root restriction. It is possible that root escapes influenced root density. Given the magnitude of effect of soil volume, (40 times) large differences would still be expected between the smallest and largest volumes.

Root restriction has been shown to have little effect on dry matter partitioning (root to shoot ratio) of peach (Ran et al., 1992; Rieger and Marra, 1994; Richards and Rowe, 1977a, 1977b) and other plant species [spreading euonymus, Dubik et al., 1990; European alder (Alnus glutinosa Gaertn.), Tschaplinski and Blake, 1985]. There have also been reports where root restriction re- duced the root to shoot ratio of peach (Erez et al., 1992; Mandre et al., 1995). In both cases, the ratio decreased from $\approx 0.24$ to 0.15 for restricted trees. In the experiment of Erez et al. (1992), there was little difference in the root to shoot ratio after harvest (Table 8). In contrast, in our experiment, root to shoot ratio increased with root confinement. This may be due to the fact that the proportion of structural and fibrous roots was not considered in our assessment nor total root length. Structural roots would greatly effect total weight but not effective root function. It is also possible that escaped roots in Years 3 and 4, induced either a root signal or physiological response causing a proliferation of roots inside the compartments of the small soil volumes. The relationship between RCA and inside root weight for the 0.025 and 0.06 $\mathrm{m}^{3}$ compartment volumes was $r^{2}=0.188$ and 0.461 respectively. 
In conclusion, the reduction of all growth parameters resulting from decreased soil volume was observed as demonstrated in other experiments (Mandre et al., 1995; Myers, 1992; Richards and Rowe, 1977a, 1977b; Rieger and Marra, 1994; Williamson and Coston, 1990; Williamson et al., 1992). Considering analysis of the escaped roots, the effect of soil volume on vegetative growth would be expected to be greater than that observed in the experiment.

RDI has been adopted extensively to control vegetative growth of deciduous trees (Boland et al., 1993; Caspari et al., 1994; Chalmers et al., 1986; Fereres and Goldhamer, 1990; Lampinen et al., 1995; Mitchell et al., 1989), however, in the current experiment, RDI had minimal influence on tree growth. The level of RDI and escaped roots may have influenced this response.

\section{Literature Cited}

Boland, A.M., P.D. Mitchell, I. Goodwin, and P.H. Jerie. 1994. The effect of soil volume on young peach tree growth and water use. J. Amer. Soc. Hort. Sci. 119:1157-1162.

Boland, A.M., P.D. Mitchell, P.H. Jerie, and I. Goodwin. 1993. Effect of regulated deficit irrigation on tree water use and growth of peach. J. Hort. Sci. 68:261-274.

Caspari, H.W., M.H. Behboudian, and D.J. Chalmers. 1994. Water use, growth and fruit yield of 'Hosui' Asian pears under deficit irrigation. J. Amer. Soc. Hort. Sci. 119:383-388.

Chalmers, D.J. 1988. The role of root growth in regulation of assimilate partitioning and productivity of annual and perennial crops. Proc. 4th Intl. Congr. Micro-irrigation Australia, Oct. 1988, Albury-Wodonga, Australia.

Chalmers, D.J., G. Burge, P.H. Jerie, and P.D. Mitchell. 1986. The mechanism of regulation of 'Bartlett' pear fruit and vegetative growth by irrigation withholding and regulated deficit irrigation. J. Amer. Soc. Hort. Sci. 111:904-907.

Chalmers, D.J. and B. van den Ende. 1975. Productivity of peach trees: Factors affecting dry-weight distribution during tree growth. Ann. Bot. 39:423-432.

Cockcroft, B. and K.A. Olsson. 1972. Pattern of new root production in peach trees under irrigation. Austral. J. Agr. Res. 21:1021-1025.

Dubik, S.P., D.T. Krizek, and D.P. Stimart. 1990. Influence of root zone restriction on mineral element concentration, water potential, chlorophyll concentration, and partitioning of assimilate in spreading euonymus [E. kiautschovica Loes. 'Sieboldiana']. J. Plant. Nutr. 13:677-99.

Erez, A., Y. Ran, and B. Bar-Yosef. 1992. The effect of restricted root volume on the development, yield and dry-matter partitioning in young fruiting peach trees. Acta Hort. 322:199-214.

Fereres, E. and D. Goldhamer. 1990. Deciduous fruit and nut trees, p. 987-1017. In: B.A. Stewart and D.R. Nielsen (eds.). Irrigation of agricultural crops. Amer. Soc. Agron. Monogr. 30.

Hameed, M.A., J.B. Reid, and R.N. Rowe. 1987. Root confinement and its effects on the water relations, growth and assimilate partitioning of tomato (Lycopersicon esculentum Mill.) Ann. Bot. 59:685-692.

Ingram, D.L., U. Yadav, and C.A. Neal. 1987. Production system comparisons for selected woody plants in Florida. HortScience 22:12851287.

Jerie, P.H., B. van den Ende, and I. Dann. 1989. Managing tree vigour and fruitfulness in deciduous orchards. Acta Hort. 240:127-134.

Lampinen, B.D., K.A. Shackel, S.M. Southwick, B. Olson, J.T. Yeager, and D. Goldhamer. 1995. Sensitivity of yield and fruit quality of French prune to water deprivation at different fruit growth stages. J. Amer.
Soc. Hort. Sci. 120:139-147.

Lill, W. 1989. A program for nearest neighbour analysis. Bul. New S. Wales Dept. Agr. Fisheries, Murray and Riverina Region, Australia. Mandre, O., M. Rieger, S.C. Myers, R. Seversen, and J.L. Regnard. 1995. Interaction of root confinement and fruiting in peach. J. Amer. Soc. Hort. Sci. 120:228-234.

Menzel, C.M., D.W. Turner, V.J. Doogan, and D.R. Simpson. 1994. Root shoot interactions in passionfruit (Passiflora sp.) under the influences of changing root volumes and soil temperatures. J. Hort. Sci. 69:553-564.

Mitchell, P.D. and D.J. Chalmers. 1982. The effect of reduced water supply on peach tree growth and yield. J. Amer. Soc. Hort. Sci. 107:853-856.

Mitchell, P.D., B. van den Ende, P.H. Jerie, and D.J. Chalmers. 1989. Responses of 'Bartlett' pear to withholding irrigation, regulated deficit irrigation, and tree spacing. J. Amer. Soc. Hort. Sci. 114:15-19.

Myers, S.C. 1992. Root restriction of apple and peach with in-ground fabric containers. Acta Hort. 322:215-219.

Ran, Y., B. Bar-Yosef, and A. Erez. 1992. Root volume influence on dry matter production and partitioning as related to nitrogen and water uptake rates by peach. J. Plant Nutr. 15:713-726.

Richards, D. 1981. Root-shoot interactions in fruiting tomato plants, p. 373-380. In: R. Brouwer et al. (eds.). Structure and function of plant roots. Martinus Nijhoff/Dr. W. Junk Publishers, The Hague, The Netherlands.

Richards, D. 1986. Tree growth and productivity-The role of roots. Acta Hort. 175:27-36.

Richards, D., F.H. Goubran, W.N. Garwoli, and M.W. Daly. 1979. A machine for determining root length. 52:69-76.

Richards, D. and R.N. Rowe. 1977a. Root-shoot interactions in peach: The function of the root. Ann. Bot. 41:1211-1216.

Richards, D. and R.N. Rowe. 1977b. Effects of the root restriction, root pruning and 6-benzylamino-purine on the growth of peach seedlings. Ann. Bot. 41:729-740.

Rieger, M. and F. Marra. 1994. Responses of young peach trees to root confinement. J. Amer. Soc. Hort. Sci. 119:223-228.

Robinson, J.B., M. Treeby, and R.A. Stephenson. 1997. Fruits, vines and nuts, p. 347-382. In: D.J. Reuter and J.B. Robinson (eds.). Plant analysis: An interpretation manual. CSIRO Publ., Melbourne, Australia.

Tschaplinski, T.J. and T.J. Blake. 1985. Effects of root restriction on growth correlations, water relations, and senescence of alder seedlings. Physiol. Plant. 64:167-176.

van den Ende, B. and D.J. Chalmers. 1982. An evaluation of commercial experience with the Tatura trellis for growing peaches. HortScience 17:218-220.

van den Ende, B., D.J. Chalmers, and P.H. Jerie. 1987. Latest developments in training and management of fruit crops on Tatura trellis. HortScience 22:561-568.

Westwood, M.N. and A.N. Roberts. 1970. The relationship between trunk cross sectional area and weight of apple trees. J. Amer. Soc. Hort. Sci. 95:28-30.

Williamson, J.G. and D.C. Coston. 1989. The relationship among root growth, shoot growth, and fruit growth of peach. J. Amer. Soc. Hort. Sci. 114:180-183.

Williamson, J.G. and D.C. Coston. 1990. Planting method and irrigation rate influence vegetative and reproductive growth of peach planted at high density. J. Amer. Soc. Hort. Sci. 115:207-212.

Williamson, J.G., D.C. Coston, and J.A. Cornell. 1992. Root restriction affects shoot development of peach in a high-density orchard. J. Amer. Soc. Hort. Sci. 117:362-367. 